\title{
IMPLEMENTATION OF 'MUDHARABAH' CONTRACTS AND THEIR IMPACTS ON FUND-RAISING PRODUCTS IN JAMBI SHARIA BANKING
}

\author{
Bahrul Ma'ani \\ UIN Sulthan Thaha Saifuddin Jambi \\ Email: bahrulmaani2018@gmail.com \\ Supyani \\ Universitas Islam Indragiri \\ Email: supyaniwanafyani@gmail.com \\ Almusrijah Aini \\ UIN Sulthan Thaha Saifuddin Jambi \\ Email: almusrijahaini96@gmail.com \\ Indah Maulinda \\ UIN Sulthan Thaha Saifuddin Jambi \\ Email: indahmaulinda25@gmail.com
}

Abstract: Funds with the 'mudharabah' principle are investment funds so that Islamic banks share the proceeds only to the owners of funds that use the 'mudharabah' principle. The collection of funds is applied to savings and deposit products that use 'mudharabah' contracts. The amount of income received by the owner of the 'mudharabah' fund is part of the income received in cash from the distribution of funds by Islamic banks. Therefore, the funds collected with the 'mudharabah' principle are one of the elements in calculating profit sharing. The problem raised in the research is how to implement the 'mudharabah' contract and its impact on fund-raising products in Islamic banking. Two main things affect the quality or results of research: the quality of research instruments and the quality of data collection. The quality of research instruments relates to the validity and reliability of the instruments and the quality of data collection regarding the accuracy of the methods used to collect data. Therefore, an instrument tested for validity and reliability may not necessarily produce valid and reliable data if the instrument is not appropriately used in collecting data. The type of research was the quantitative technique used through interviews, observations, and documentation. In analyzing the data obtained, the authors used descriptive techniques. The results showed that applying 'mudharabah' contracts to fund-raising products at Islamic banks is only applied to savings and deposit products, and the advantages of products that use 'mudharabah' contracts are basically to make it easier for customers to transact. These products can be used as financing guarantees. There are supporting and inhibiting factors in the products that use 'mudharabah' contracts. These supporting factors include the existence of Islamic sharia principles, 
which are used as a reference for implementing a profit-sharing system on all products, especially savings and deposit products, and the existence of infrastructure facilities within the company that are pretty complete. Meanwhile, the inhibiting factors include the lack of socialization regarding Islamic banks' existence.

Keywords: mudharabah, implementation, impact, funds raising products, syariah banking.

Abstrak: Dana dengan prinsip 'mudharabah' adalah dana investasi sehingga bank syariah membagi hasil hanya kepada pemilik dana yang menggunakan prinsip 'mudharabah'. Penghimpunan dana diterapkan pada tabungan dan deposito dengan akad mudharabah. Besarnya pendapatan yang diterima oleh pemilik dana mudharabah merupakan bagian dari pendapatan yang diterima secara tunai dari penyaluran dana oleh bank syariah. Oleh karena itu, dana yang dihimpun dengan prinsip 'mudharabah' menjadi salah satu unsur dalam menghitung bagi hasil. Masalah yang diangkat dalam penelitian ini adalah bagaimana penerapan akad mudharabah dan dampaknya terhadap penghimpunan dana di perbankan syariah. Dua hal utama yang mempengaruhi kualitas atau hasil penelitian: kualitas instrumen penelitian dan kualitas pengumpulan data. Kualitas instrumen penelitian berkaitan dengan validitas dan reliabilitas instrumen serta kualitas pengumpulan data mengenai ketepatan metode yang digunakan untuk mengumpulkan data. Jenis penelitian yang digunakan adalah teknik kuantitatif melalui wawancara, observasi, dan dokumentasi. Dalam menganalisis data yang diperoleh, penulis menggunakan teknik deskriptif. Hasil penelitian menunjukkan bahwa penerapan akad mudharabah pada produk penghimpunan dana di bank syariah hanya berlaku pada produk tabungan dan deposito, dan keunggulan produk yang menggunakan akad mudharabah pada dasarnya adalah untuk memudahkan nasabah dalam bertransaksi. Produk-produk ini dapat digunakan sebagai jaminan pembiayaan. Ada faktor pendukung dan penghambat dalam produk yang menggunakan akad mudharabah. Faktor pendukung tersebut antara lain adanya prinsip syariah Islam yang dijadikan acuan penerapan sistem bagi hasil pada semua produk khususnya produk tabungan dan deposito, serta adanya sarana prasarana di dalam perusahaan yang cukup lengkap. Sedangkan faktor penghambatnya antara lain kurangnya sosialisasi tentang keberadaan bank syariah.

Kata-kata kunci: mudharabah, implementasi, dampak, produk penghimpunan dana, perbankan syariah.

\section{Introduction}

Islamic Banks are intermediary institutions and financial service providers that work based on Islamic ethics and systems, for instance: free from interest (riba), free from speculative activities and gambling (maysir), and free from things that are not clear (gharar), with the principle of justice. ${ }^{1}$ Furthermore, only finance halal business activities, which are sharia banking principles. Islamic banks are often equated with interest-free banks. Interest-free banks are a narrower concept than Islamic banks, where some instruments or operations are free of interest. ${ }^{2}$ In addition to avoiding interest, Islamic banks also actively participate in achieving the goals and objectives of an Islamic economy oriented towards social welfare. Money

\footnotetext{
${ }^{1}$ M. Nur Rianto, dkk., Teori Mikroekonmi: Suatu Perbandingan Ekonomi Islam dan Ekonomi Konvensional, Jakarta: Kencana, 2010. p.19

2Muhammad Amin Summa, Tafsir Ayat Ekonomi Teks, Terjemah, dan Tafsir, (Jakarta: Amazah, 2018), p.164 
deviation in Islamic banks is an investment made in assets whose condition and origin are appropriately disclosed and the management process and the distribution of the results ${ }^{3}$.

According to Article 1 of Law No. 4 of 2003 concerning Banking, Banks are commercial banks and Rural Banks that carry out business activities conventionally or based on Sharia principles, which do not provide services in payment traffic. In the bank's function as an intermediary between depositors and creditors, the bank must carry out activities to collect funds from the depositors, which will later be distributed to creditors. The purpose of fund-raising activities is to increase capital, enlarge assets, and enlarge financing activities to support the function of banks as intermediary institutions ${ }^{4}$.

Meanwhile, Islamic banking is regulated in Law no. 21 of 2008 concerning Islamic banking. The article states that Islamic commercial banks can only be established and/or owned by: a. Indonesian citizen and/or Indonesian legal entity; b. Indonesian citizens and/or Indonesian legal entities with foreign citizens and/or foreign legal entities in partnership; or e. Local government ${ }^{5}$.

The considerations for the law are, first, that in line with the national development goals to create a just and prosperous society based on economic democracy, an economic system is developed based on the values of justice, togetherness, equity, and benefits under sharia principles. Second, the Indonesian people's needs for sharia banking services are increasing. Third, that Islamic banking has specificity compared to conventional banking. ${ }^{6}$ Fourth, the regulation regarding Islamic banking in Law No. 7 of 1992 concerning banking as amended by Law no. 10 of 1998 is not yet specific, so it needs to be specifically regulated in a separate law ${ }^{7}$.

The study of the application of sharia principles in sharia banking operations is an essential agenda for national banking. Bank Indonesia has reviewed the standardization of sharia banking product contracts starting with 'mudharabah', 'musyarakah', and 'murabahah' contracts, to identify the application of sharia principles and possible variations in practice. On the other hand, the public has a perception that Islamic Banks are different by having a higher quality, ethics, and business compared to a conventional bank. The primary purpose of the 'mudharabah' contract is to obtain investment returns where the funds that Islamic Banks have collected from third-party funds or other deposits need to be manage full with trust and 'istiqomah'. With the hope that these funds will bring big profits, both for customers and Islamic banks. The main principle that Islamic banks must develop concerning funding management is that Islamic banks must provide profit sharing for depositors of funds at least equal to or greater than the debtor, lower than the interest rate applicable in conventional banks. ${ }^{8}$ In banking, 'mudharabah' is usually applied to financing or funding products such as working capital financing. Funds for 'mudharabah' activities are taken from time savings deposits such as 'hajj'

${ }^{3}$ Wiku Suryomurti, Supercerdas Investasi Syariah, (Jakarta: PT. AgreMedia Pustaka, 2011).

${ }^{4}$ Banking regulation,

(https://www.ojk.go.id/id/kanal/perbankan/regulation/undang/Pages/undang-undang-nomor-3tahun-2004-about-change-over-undang-undang-republik-indonesia-number-23-year-1999-aboutba.aspx Accessed on 24-10-2021).

${ }^{5}$ Neneng Nurhasanah, et al., Perbankan Syariah:Konsep dan Regulasi, (Jakarta: Sinar Grafika, 2017). p. 25

${ }^{6}$ Adrian Sutedi, Aspek Hukum Obligasi \& Sukuk, Jakarta: Sinar Grafika 2009.p.146

${ }^{7}$ Neni Sri Imaniyati, Perbankan Syariah dalam Perspektif Hukum Ekonomi, (Bandung: Mandar Maju, 2013), p. 59

${ }^{8}$ Hudhory, Muhammad Syarif, Sistem Ekonomi Islam, (Jakarta: Kencana, 2012), p.23 Innovatio, Vol. XXI, No. 2, July-December 2021 
savings or 'qurban' savings. Funds can also be made from ordinary deposits and special deposits deposited by customers for certain businesses. To meet these capital and financing needs, Islamic Banks have different provisions from Conventional Banks. In general, the tools used by Islamic banks consist of three categories, namely fund-raising products, fund distribution products, and service products.

Similar to conventional banking products, the public entrusts Islamic banking products in raising funds to banks based on fund deposit agreements in the form of Current Accounts, Deposits, Certificates of Deposits, Savings, and other equivalent forms. The implementation of sharia principles in current accounts uses 'wadiah' contracts and 'mudharabah' contracts, and deposits only use profit-sharing 'mudharabah' contracts because this deposit product is intended as an investment vehicle. At the same time, savings customers can choose to use 'wadiah' or 'mudharabah' (profit sharing) contracts. ${ }^{9}$ The product of raising funds by implementing the 'mudharabah' contract has been implemented in Islamic Banks where the application of this product can bring benefits to banks and customers. Banks can expand customers, and gain customer loyalty and get profits or margins. Meanwhile, customers get the currency needed for transaction purposes.

With the above problems, are Islamic banks able to develop and realize their sharia products, especially Islamic banks in Jambi City? In this case, how are Islamic banks applying 'mudharabah' contracts to their fund-raising products, and what is the impact of these contracts besides how Islamic banks can attract trust from the public that all products implement contracts in Islamic banks that are under sharia 10 .

Therefore, this study aims to explore whether Jambi Islamic banks can accommodate the public interest and the interests of Muslims in particular or not, especially for the Islamic community. Likewise, to research and explain the implementation of the 'mudharabah' contract and its impact at the same time on fund-raising products in Islamic banking. ${ }^{11}$

The technique of data collection and analysis is descriptive research ${ }^{12}$. Descriptive is a method that describes or provides an overview of the object to be studied through data or samples that have been collected that are applicable to the public $^{13}$. In other words, descriptive analysis by researching and trying to get accurate and correct data, then the data is described and discussed systematically to produce conclusions as alternative solutions to problems encountered.

The source of research data is an important factor that is considered in determining the method of data collection, in addition to the types of data discussed above $^{14}$. The source of this research data comes from secondary data. Secondary data is a source of research data obtained by researchers indirectly through intermediaries (obtained and recorded by other parties). Secondary data is

\footnotetext{
${ }^{9}$ Zainuddin Ali, Hukum Asuransi Syariah, (Jakarta: Sinar Grafika, 2008), p.144

10Ibid., p. 162

${ }^{11}$ Havis Aravik, Ekonomi Islam: Konsep, Teori, dan Aplikasi Serta Pandangan Pemikir Ekonomi Islam, Malang, Empatdua, 2016. p.24

${ }^{12}$ Sugiono. Metode Penelitian Kombinasi, (Bandung: Alfabeta. 2013), p.56

${ }_{13}^{13}$ Ibid., Metode Penelitian Kuantitif Kulitatatif dan R\&D, (Bandung: Alfabeta, 2011), p. 581.

${ }^{14}$ Rianto, Teori Mikroekonmi: Suatu Perbandingan Ekonomi Islam dan Ekonomi Konvensional, (Jakarta: Kencana, 2010), p.67. 
generally in the form of evidence, historical records, or reports that have been compiled in published and unpublished archives (documentary data) ${ }^{15}$.

Data collection in this study are: This research was conducted by reviewing reference books, literature, and brochures related to this research. That is how to collect data by categorizing and classifying written materials related to research problems, both from document sources and books, newspapers, magazines, and others. In this study, the author's data collection method is documentation, namely the collection of data obtained through electronic media such as the internet.

The analysis used by the author is the descriptive analysis method, which is a research method that describes the object of research in the form of existing data. As explained by Pattom in the book "Interdisciplinary Qualitative Religious Research Methods" by Kailani, the notion of analysis is the process of arranging data sequences, organizing them into a pattern, category, and basic unit of description. In addition, researchers also carry out an interpretation and interpretation of the analysis process, explain patterns or categories, look for relationships between elements with one another and then formulate theoretical constructions ${ }^{16}$. Then it is explained by reducing data, clarifying data, and displaying data.

\section{Implementation}

Implementation comes from English, namely to implement, which means to implement. Implementation is the provision of means to carry out something that impacts or affects something. Something that is done to have an impact or consequence can be in the form of laws, government regulations, judicial decisions, and policies made by government institutions in state life.

According to Janwari ${ }^{17}$ suggests that implementation is an engineering system. Implementation boils down to the activity, the action, or the system's mechanism. The expression mechanism implies that implementation is an activity and an activity that is planned and carried out seriously based on certain norms to achieve the activity's objectives. The Fund-raising product is a business activity carried out by banks to seek funds from depositors, which will later be distributed to creditors to carry out their function as intermediaries between depositors and creditors.

The collection of funds in Islamic banks can be in the form of demand deposits, savings, and time deposits. ${ }^{18}$ The operational principles of sharia applied in the collection of public funds are the principles of 'wadiah' and 'mudharabah'. The principle applied is 'wadiah yad dhamanah' which is applied to checking account products. 'Wadiah yad dhamanah' is different from 'wadi'ah amanah'. In 'wadi'ah amanah's' principle, the deposited property should not be used by the entrusted person. Meanwhile, in the case of 'wadi'ah yad dhamanah', the entrusted party (BMT) is responsible for the integrity of the deposited property so that he may take advantage of the deposited property ${ }^{19}$.

15Suratman, dkk., Metodae Penelitian Hukum, (Bandung: Alfabeta, 2012), p.147

${ }^{16}$ Kailani, Penelitian Agama Interdisipliner, (Yogyakarta, 2010), p.162.

${ }^{17}$ Yadi Janwari, Peradaban Ekonomi Islam: Pada Masa Keemasan dan Kebangkitan, (Bandung: PT. Remaja Rosdakarya, 2017), p.16.

18 Departemen Ekonomi dan Keuangan Syariah Bank Indonnesia, Usaha Mikro Islam, (Bank Indonesia: Universitas Pajajran: 2016), p. 17.

${ }^{19}$ Neni Sri Imaniyati, Op. Cit., p 101 
In applying the 'mudharabah' principle, the depositor acts as 'shahibul maal' (owner of capital), and the Bank/BMT as 'Mudharib' (manager). The Bank/BMT uses the funds to perform 'murabahah' or 'ijarah'. The Bank/BMT can also use the funds to perform 'mudharabah' first. The results of this business will be divided according to the agreed ratio. In the event that the Bank/BMT uses it to perform the Second 'mudharabah', the Bank/BMT is fully responsible for the losses incurred. ${ }^{20}$

In the 'mudharabah' principle, the one who calculates the distribution of operating results is the 'mudharib' (fund manager) because one of the characteristics of the 'mudharabah' principle is that the work is completely left to the 'mudharib' (fund manager). The fund owner may not interfere in the management of 'mudharabah' funds so that the one who knows the business results is the 'mudharib'. Therefore, it is 'mudharib' who calculates the distribution of operating results.

The pillars of 'mudharabah' are perfectly fulfilled (when there are 'mudharib', there are owners of funds, there is a business that will be shared, there is a ratio, and there is an ijab qabul). The 'mudharabah' principle is applied to Savings and Time Deposits products. Based on the authority given to the depositor of funds, the 'mudharabah' principle is divided into two, namely 'mudharabah Mutlaqah', 'mudharabah Muqayyadah'.

In conventional banks, the collection of funds from the public is carried out in the form of Savings, Time Deposits, and Current Accounts, which are commonly called third-party funds. In Islamic banks, the collection of funds from the public does not distinguish the product name but looks at the principles, namely the 'wadiah' principle and the 'mudharabah' principle. Whatever the product name, what is considered is the principle used for the product. It is closely related to the number of business results obtained that will be taken into account in the distribution of operating results to be carried out between the owner of the funds or depositors (shahibul mall) and the Islamic Bank as the fund manager (mudharib).

The implementation of 'mudharabah' contracts on fund-raising products in demand deposits, time deposits, certificates of deposit, and savings products are as follows:

\section{A. Giro}

This current account product can use 'wadiah' or 'mudharabah' contracts. In the demand deposits that use a 'wadiah' contract, the bank can use the deposited funds used in the 'wadiah yad dhamanah' contract as the recipient of the deposited funds. The bank later will reward the depositing customer with some bonuses, which are according to bank policy and are not agreed upon in advance. Whereas a bank uses 'mudharabah' contract in its operations, the profit sharing ratio is determined between the bank and the customer at the beginning of the agreement.

\section{B. Deposit}

Because it is intended as an investment facility, the deposit product is only used in Islamic banking practices using 'mudharabah' contracts. Through 'mudharabah' contract, the profit-sharing ratio has been determined for the customer and the Islamic Bank itself at the beginning of the agreement.

${ }^{20}$ Muhammad, Sistem Bagi Hasil dan Pricing Bank Syariah, (Yogyakarta: UII Press: 2016), p. 7 


\section{Savings}

As with current accounts, customers can choose to use 'Wadi'ah' or 'mudharabah' contracts in this savings product. The benefits and risks are the same as current accounts, while the difference lies in the mechanism for withdrawing funds deposited by customers.

Basically, fund-raising products are applied to savings and time deposits with 'mudharabah' contracts. The advantages of products that use 'mudharabah' contracts in savings products include investment facilities in the form of savings, which can be used as financing guarantees, and a network of transaction sites such as ATMs.

The Impact of Products using 'mudharabah' Contracts on Islamic Banking:

a. Positive impact

1. There is a growing number of 'mudharabah' investments that increase every year.

2. There is an increasing number of 'mudharabah' customers every year.

3. The development of an increase in the nominal 'mudharabah', which increases every year.

b. Negative impact

1. Ineffective dual banking system can make funds from Islamic banks mixed with funds from conventional banks.

2. There are fears of abuse in Islamic banking, which still practices usury.

The supporting factor that makes the 'mudharabah' contract acceptable to the public is one of the supporting factors is bringing the brand of each Islamic banking. In addition to the supporting factors, the inhibiting factor is the lack of publication from the company so that the public does not know the existence of Islamic banking itself.

\section{Closing}

In the description above, it can be concluded that basically, fund-raising products are applied to savings and deposit products with 'mudharabah' contracts. The advantages of products that use 'mudharabah' contracts in savings products include being a means of investment in the form of savings and can be used as financing guarantees.

This deposit is carried out with the 'mudharabah muthlaqah' principle because the management of the deposit fund is fully the responsibility of the 'mudharib' (bank). 'mudharabah' deposits are fund deposits under a 'mudharabah' contract. The owner of the funds (shahibul mall) entrusts the funds to be manage by the bank (mudharib) with profit sharing following the agreed ratio from the start.

\section{BIBLIOGRAPHY}

Adrian Sutedi, Aspek Hukum Obligasi \& Sukuk, Jakarta: Sinar Grafika 2009.

Abdul Ghofur Anshori, Penerapan Prinsip Syariah dalam Lembaga Keuangan Lembaga Pembiayaan Dan Perusahaan Pembiayaan, Yogyakarta: Pustaka Pelajar, 2008.

Abdullah Saed, “Bank Islam dan Bunga”, Yogyakarta: Pustaka Pelajar, 2004.

Departemen Ekonomi dan Keuangan Syariah Bank Indonnesia, Usaha Mikro Islam, Bank Indonesia: Universitas Pajajran: 2016. 
Muhammad, Sistem Bagi Hasil dan Pricing Bank Syariah, Yogyakarta: UII Press: 2016.

Muhammad Amin Summa, Tafsir Ayat Ekonomi Teks, Terjemah, dan Tafsir, Jakarta: Amazah, 2018.

Muhammad Syarif Hudhory, Sistem Ekonomi Islam, Jakarta: Kencana, 2012.

Neneng Nurhasanah dan Panji Adam, Hukum Perbankan Syariah: Konsep dan Regulasi, Jakarta: Sinar Grafika, 2017.

Neni Sri Imaniyati, Perbankan Syariah dalam Perspektif Hukum Ekonomi, Bandung: Mandar Maju, 2013.

Sugiyono, Metode Penelitian Kuantitif Kulitatatif dan R\&D, Bandung: Alfabeta, 2011. Metode Penelitian Kombinasi, Bandung: Alfabeta. 2013.

Suratman, dkk., Metodae Penelitian Hukum, Bandung: Alfabeta,2012.

Havis Aravik, Ekonomi Islam: Konsep, Teori, dan Aplikasi Serta Pandangan Pemikir Ekonomi Islam, Malang, Empatdua, 2016.

Wiku Suryomurti, Supercerdas Investasi Syariah, Jakarta: PT. AgreMedia Pustaka, 2011.

Yadi Janwari, Peradaban Ekonomi Islam: Pada Masa Keemasan dan Kebangkitan, Bandung: PT. Remaja Rosdakarya, 2017.

Zainuddin Ali, Hukum Asuransi Syariah, Jakarta: Sinar Grafika, 2008.

(https://www.ojk.go.id/id/kanal/perbankan/regulation/undang/Pages/undangundang-nomor-3-tahun-2004-about-change-over-undang-undang-republikindonesia-number-23-year-1999-about-ba.aspx Accessed on 24-10-2021 